\title{
Export Earnings, Capital Instability and

\author{
Economic Growth in South Asia
}

\section{Muhammad Aslam Chaudhary and Amjad Naveed*}

\section{Introduction}

During the last two decades the role of international trade and flow of foreign capital have received considerable attention in the literature. Various studies have examined the impact of export instability and capital instability on economic growth in less developed countries. ${ }^{1}$ Empirical evidence supports the hypothesis of a deleterious impact of export instability on economic growth. However, some studies also indicated that the relationship was unstable but positive with economic growth. ${ }^{2}$ Yet there are no systematic empirical investigations into the implied links between export diversification and long-term economic growth, particularly in the case of South Asian countries. The major concern regarding export instability is that it retards economic growth. The theoretical rationale for the same is that export instability creates uncertainty in the supply of foreign exchange earnings, discourages capital formation and hence hampers economic growth. ${ }^{3}$ Another notion is that capital instability affects economic growth more significantly than that of exports instability. ${ }^{4}$ When a country uses other sources to finance development than export earnings, it leads to forced savings and foreign aid for funding investment projects, and then the speed and volume of capital formation determines economic growth, not the instability of export earnings. Thus, if there is instability in mobilising capital itself, it will be pernicious to output growth. As a result, it will affect economic growth more than export earning instability. ${ }^{5}$

\footnotetext{
* The authors are Associate Professor and graduate student respectively, Department of Economics, Quaid-I-Azam University, Islamabad, Pakistan. The views expressed are entirely those of the authors. They are thankful to Dr. S. M. Younis Jaffery and Dr. Shah Nawaz Malik for their valuable comments which helped to improve the study.

1 See for example, MacBean (1966), Glezakos (1973), Vovodas (1974), Yotoupolos and Nugent (1976), Moran (1983), Savvides (1984) and Glezakos (1984).

${ }^{2}$ For unstable relationship see Moran (1983), Kenen and Voivodas (1972). For positive relationship between economic growth and export instability, see Savvides (1984), Yotoupolos and Nugent (1976), Knudsen and Parnes (1975) and MacBean (1966).

${ }^{3}$ See Nurkse (1958), MacBean (1966) and Glezakos (1984).

${ }^{4}$ See Glezakos (1984, and Fosu (1991).

${ }^{5}$ See for detail, Hawkins, Epstein and Gonzales (1966) and Voivodas (1974).
} 
Keeping in view the above theoretical linkages, the present paper is focussed on exploring linkages between export instability, capital instability and economic growth. A hypothesis will be tested whether instability associated with capital formation is affecting economic growth or fluctuations in export earnings are a bottleneck to economic growth. Moreover, impact of foreign exchange instability on economic growth will also be investigated. The analysis pertains to selected South Asian countries, which constitute more than $80 \%$ of the South Asian economy, i.e. Pakistan, India, Bangladesh, and Sri Lanka.

\section{Methodology}

Following the standard augmented production framework, [Fosu (1991), Balassa (1985), Feder (1982), Michaely (1977), and Maizels (1968)], output is not only a function of traditional new classical inputs of labour and capital but also of exports as stated below.

$Q=Q(L, K, X)$

Where $\mathrm{Q}$ is real aggregate output; $\mathrm{L}$ and $\mathrm{K}$ are labour and capital inputs, respectively; and $\mathrm{X}$ denotes exports. Exports are usually employed to reflect international factors influencing economic growth. The beneficial effects of these international factors channelised through the export sector included the following. ${ }^{6}$

i. It encourages specialisation and competitiveness and therefore improves production.

ii. Advantage of large scale economies, and

iii. Adoption of relatively efficient techniques to compete in the world.

Based upon equation (1), the following equation (2) may be derived for estimation.

$G Q=\alpha_{0}+\alpha_{1} G L+\alpha_{2} G K+\alpha_{3} G R X+\mu$

Where $G Q, G L, G K$ and $G R X$ are growth rates of output, labour, capital and exports, respectively. ${ }^{7} \alpha i(i=1,2,3)$ measures the impact of the

\footnotetext{
${ }^{6}$ See detail Fosu (1991).

${ }^{7} \mathrm{GK}$ is the gross domestic investment as a percentage of GNP.
} 
respective functional argument; $\alpha_{0}$ is the intercept; $\mu$ is the stochastic term. The complete model may be specified as:

$G Q=\alpha_{0}+\alpha_{1} G L+\alpha_{2} G K+\alpha_{3} G R X+\alpha_{4} I K+V_{t}$

Where $I K$ is capital intensity.

$V_{t}$ is the error term.

To differentiate between capital instability and export instability, equation (3) may be written as:

$$
G Q=\alpha_{0}+\alpha_{1} G L+\alpha_{2} G K+\alpha_{3} G R X+\alpha_{4} I K+\alpha_{5} I X+V_{t} \ldots
$$

Where $I X$ is a measure of export instability.

Foreign exchange is regarded as vital to the economic growth of less developed countries (LDCs). The unavailability of foreign exchange is a major constraint in financing imports. It is also considered an important determinant of capital formation and GDP growth. ${ }^{8}$ Thus fluctuations in foreign exchange receipts are believed to generate obstacles to development and economic planning. To test this notion, we add a new variable in equation (4) that is instability in foreign exchange reserves (IRS).

$$
G Q=\alpha_{0}+\alpha_{1} G L+\alpha_{2} G K+\alpha_{3} G R X+\alpha_{4} I K+\alpha_{5} I X+\alpha_{6} I R S+V_{t}
$$

Where $G L, G K$ and $G R X$ are the growth rates of labour, capital and exports, and $I X, I K$ and $I R S$ are the measures of export instability, capital instability and instability in foreign exchange reserves, respectively. According to neo-classical theory, $\alpha_{1}$ and $\alpha_{2}$ are non-negative, and $\alpha_{3}$ are positive. The capital instability and the foreign exchange reserves instability may be more harmful than the usual hypothesis of export instability.

The results of the models are discussed in the next section.

\section{Empirical Results}

The present section consists of empirical findings pertaining to export instability, capital instability, foreign exchange instability and economic growth

\footnotetext{
${ }^{8}$ For detail see, Massell, Pearson and James (1972).
} 
for selected South Asian countries i.e. Pakistan, India, Bangladesh and Sri Lanka.

\section{1: Empirical Evidence pertaining to Pakistan}

The results obtained by multiple regression estimates of equation (4) and equation (5) of our basic models are reported in Table 1 and 1.1, respectively. All regression equations are corrected for auto-correlation by applying the AR (1) and MA (1) process.

First equation (a) of Table 1 is estimated for all variables in equation (4), i.e. growth rate of labour force $(G L)$, exports $(G R X)$, and capital $(G K)$ and exports and capital instability. Two variables, growth rate of capital $(G K)$ and capital instability $(I K)$, are found to be significant at the 10 percent level. The signs of capital instability $(I K)$ and export instability $(I X)$, are both negative and $L X$ is also insignificant. It appears that the capital instability variable $(I K)$ and export instability variable $(I X)$ are hampering the growth process. Capital instability has a larger magnitude than export instability for Pakistan. It confirms our hypothesis that capital instability (IK) is more harmful to GDP growth than export instability $(I X)$.

To check the effect of $I K$ separately, we omitted the variable $I X$ and estimate equation (b) again. Results of equation (b) are slightly different from equation (1). $R^{2}$ falls slightly but ' $t$ ' values increase for capital instability, from 10 percent to 5 percent. ' The ' $F$ ' statistic also improves at a moderate level. Another variable, growth rate of exports $(G R X)$, also becomes significant and it has a positive impact on economic growth. It means that the growth rate of exports promotes economic growth, whereas instability in capital stock is the major affecting variable for economic growth, compared to export instability.

To identify the separate effect of the export instability variable on economic growth, we dropped the capital instability variable $(I K)$ and estimated equation (c). The coefficient of export instability has a negative sign but still insignificant. F Stat and $\mathrm{R}^{2}$ also fall slightly. If we compare equation (b) with equation (c), it becomes clear that the more effective variable in the growth equation is capital instability rather than export instability. ${ }^{10}$ This suggests that the economic growth of Pakistan is more affected by capital instability than by exports instability.

\footnotetext{
${ }^{9}$ The variables $I K$ and $I X$ are highly correlated in equation (1). Multicollinearity problem may arise. Thus, when we dropped one variable the results improved. See Appendix Table: A.1.

${ }^{10}$ MacBean (1966) Fosu (1990) and Qaisrani (1996) also found the same results.
} 
Table 1: Pakistan: Export Instability, Capital Instability and Economic Growth: Results of Multiple Regression Equation (Dependent Variable is GDP Growth)

\begin{tabular}{llll}
\hline Variables/equations & (a) & (b) & (c) \\
\hline $\mathbf{C}$ & -15.64 & -15.005 & -27.69 \\
$\boldsymbol{G L}$ & $(-1.17)$ & $(-1.198)$ & $(-2.62)^{* *}$ \\
& 0.025 & 0.041 & 0.055 \\
$\boldsymbol{G} \boldsymbol{K}$ & $(0.026)$ & $(0.044)$ & $(0.585)$ \\
& 0.746 & 0.764 & 1.41 \\
$\boldsymbol{G} \boldsymbol{R} \boldsymbol{X}$ & $(1.99)^{* * *}$ & $(1.78)^{* * *}$ & $(2.34)^{*}$ \\
$\boldsymbol{I K}$ & 0.006 & 0.62 & 0.01 \\
& $(0.164)$ & $(1.971)^{* * *}$ & $(0.234)$ \\
$\boldsymbol{L X}$ & -2542.94 & -2378.71 & - \\
& $(-1.781)^{* * *}$ & $(-2.16)^{* * *}$ & \\
AR(1) & -667.23 & - & -13.88 \\
& $-0.40)$ & & $(-0.018)$ \\
MA(1) & 0.32 & 0.33 & 0.41 \\
$\mathbf{R}^{2}$ & $(1.76)^{* * *}$ & $(1.864)^{* * *}$ & $(2.315)^{* * *}$ \\
D.W. & - & - & - \\
F stat & 0.51 & 0.49 & 0.43 \\
\hline
\end{tabular}

Note: Figures in Parentheses are t-statistics.

*Significant at 1 percent ${ }^{* *}$ Significant at 5 percent. ***Significant at 10 percent. $G L=$ Average annual percent growth rate of the labour force. $G K$ $=$ Growth rate of Capital, measured as the mean annual gross domestic investment as a percentage of GDP. $G R X=$ Average annual percent growth rate of exports. $I K=$ Capital instability. $L X=$ Export instability.

\subsubsection{Foreign Reserves Instability and Economic Growth}

The results of equation (5) are reported in Table 1.1. Equation (a) is estimated for all variables including foreign exchange instability. Only a single coefficient, capital instability $(I K)$ is significant at the 10 percent level and all other variables are insignificant. One reason could be that $I K$ and $I X$ are correlated and $I K$ is also correlated with $I R S .^{11}$ We dropped the $I X$ and estimate the new equation (b), including $I R S$ variable. Now three variables, growth rate of capital $(G K)$, growth rate of exports $(G R X)$ and capital instability (IK) are significant, and have the expected sign except instability in foreign reserves

${ }^{11} I R S$ and $I K$ are correlated and may create problems of multicollinearity, so we dropped one variable and then estimated it. For details see appendix Table 1. 
(IRS), which is insignificant. It means that by inclusion of IRS, results do not improve much. By dropping $I K$ and including $I X$, equation (c) is estimated. But the IRS is still insignificant. Which suggests that foreign exchange reserves do seem to affect the economic growth of Pakistan.

To check the effect of instability in foreign exchange reserves on economic growth separately, we dropped the $I K$ and $I X$ variable in equation (d). The results indicate the same behaviour for $I R S$ as in previous equation (b). It suggests that instability in foreign exchange reserves does not affect economic growth. It may be noted that the level of foreign exchange is not very high in Pakistan, which means that its dependency on reserves is negligible.

Our findings suggest that capital formation affects economic growth more than export earning instability. It implies that fluctuations in exports does lead to similar fluctuations in the ability to import because capital stocks of underdeveloped countries are limited. Thus, fluctuations in exports will lead to fluctuations in capital formation and hence affects the economic growth process. It might be more desirable to reduce the fluctuations in investable funds directly. 
Table 1.1: Pakistan: Export Instability, Capital Instability and Economic Growth: Results of Multiple Regression Equation (Dependent Variable is GDP Growth)

\begin{tabular}{lllll}
\hline Variables & (a) & (b) & (c) & (d) \\
\hline $\mathbf{C}$ & -14.265 & -14.15 & -27.61 & -27.71 \\
& $(-1.058)$ & $(-1.105)$ & $(-2.55)^{*}$ & $(-2.66)^{*}$ \\
$\boldsymbol{G L}$ & 0.063 & 0.058 & 0.101 & 0.10 \\
& $(0.064)$ & $(0.061)$ & $(0.104)$ & $(0.11)$ \\
$\boldsymbol{G} \boldsymbol{K}$ & 0.723 & 1.32 & 1.412 & 1.414 \\
& $(1.029)$ & $(2.10)^{* *}$ & $(2.276)^{* *}$ & $(2.34)^{* *}$ \\
$\boldsymbol{G} \boldsymbol{R} \boldsymbol{X}$ & 0.014 & 0.38 & 0.013 & 1.21 \\
& $(0.328)$ & $(2.01)^{* * *}$ & $(0.309)$ & $(1.99)^{* * *}$ \\
$\boldsymbol{I} \boldsymbol{K}$ & -2691.93 & -2564 & - & - \\
& $(-1.73)^{* * *}$ & $(-1.69)^{* * *}$ & & \\
$\boldsymbol{L} \boldsymbol{X}$ & -556.509 & - & -59.64 & - \\
& $(-0.324)$ & & $(-0.033)$ & \\
$\boldsymbol{I R S}$ & -237.46 & -2.549 & -119.038 & -116.43 \\
& $(-0.479)$ & $(-0.531)$ & $(-0.242)$ & $(-0.245)$ \\
AR(1) & 0.33 & 0.335 & 0.409 & 0.41 \\
& $(1.73)^{* * *}$ & $(1.821)^{* * *}$ & $(2.297)^{* *}$ & $(2.42)^{* *}$ \\
$\mathbf{R}^{2}$ & 0.51 & 0.50 & 0.46 & 0.45 \\
D.W & 2.11 & 2.12 & 2.12 & 2.12 \\
F stat. & 3.56 & 3.85 & 3.35 & 3.58 \\
\hline
\end{tabular}

Note: Figures in Parentheses are t-statistics. of GDP.

$G R X=$ Average annual percent growth rate of exports. IK= Capital instability. ${ }^{* * *}$ Significant at $10 \%$. ${ }^{*}$ Significant at 1 percent. ${ }^{* *}$ Significant at 5 percent. $G L=$ Average annual percent growth rate of the labour force. $G K=$ Growth rate of Capital, measured as the mean annual gross domestic investment as a percentage. $L X=$ Export instability.

I $R S=$ Instability in foreign exchange reserves. 
Table 2: India: Export Instability, Capital Instability and Economic Growth: Results of Multiple Regression Equation (Dependent Variable is GDP Growth

\begin{tabular}{llll}
\hline Variables & (a) & (b) & (c) \\
\hline $\mathbf{C}$ & 41.40 & 24.429 & 4.44 \\
& $(1.625)$ & $(2.17)$ & $(0.95)$ \\
$\boldsymbol{G L}$ & 6.22 & 6.829 & 0.048 \\
& $(1.64)$ & $(1.605)$ & $(1.654)$ \\
$\boldsymbol{G} \boldsymbol{K}$ & 1.196 & 0.584 & 0.62 \\
& $(1.372)$ & $(1.899)^{* * *}$ & $(1.98)^{* * *}$ \\
$\boldsymbol{G} \boldsymbol{R} \boldsymbol{X}$ & 0.032 & 0.46 & -0.054 \\
& $(1.612)$ & $(1.92)^{* * *}$ & $(-1.34)$ \\
$\boldsymbol{I K}$ & -31511.8 & -26097.51 & - \\
& $(-2.323)^{* *}$ & $(-2.367)^{* *}$ & \\
$\boldsymbol{I X}$ & -6212.81 & - & -2497.61 \\
& $(-0.761)$ & & $(-1.448)$ \\
AR(1) & - & - & - \\
MA(1) & -0.904 & -0.963 & - \\
& $(-3.79)^{*}$ & $(-5.595)^{*}$ & \\
$\mathbf{R}^{2}$ & 0.51 & 0.50 & 0.46 \\
D.W. & 1.96 & 1.97 & 2.201 \\
F stat. & 3.54 & 3.97 & 3.39 \\
\hline
\end{tabular}

Note: Figures in Parentheses are t-statistics.

*Significant at 1 percent. ${ }^{* *}$ Significant at 5 percent. ${ }^{* * *}$ Significant at 10 percent. $G L=$ Average annual percent growth rate of the labour force. $G K=$ Growth rate of Capital, measured as the mean annual gross domestic investment as a percentage of GDP. $G R X=$ Average annual percent growth rate of exports. $I K=$ Capital instability. $I X=$ Export instability.

\subsection{Empirical Evidence pertaining to India}

Equation (4) and equation (5) of the model are also estimated for India. The results are reported in Table 2 and $2.1^{12}$. Equation (a) of Table 2 is estimated including all the variables in equation (4). Only a single variable, capital instability $(I K)$ is found to be significant at 5 percent. The signs of capital instability $(I K)$ and export instability $(L X)$ are both negative, but IX insignificant. Thus, it confirms our hypothesis that capital instability affects

\footnotetext{
${ }^{12}$ All the regression equations are corrected for autocorrelation by using AR (1) and MA
} (1) process. 
GDP growth more than export instability $(L X)$ for India, which suggests that fluctuations in capital stock exist in the Indian economy and have effects on the economic growth of India. To retrieve the effect of $I K$ separately, we omitted the variable $X X$ and estimated equation (b). Results of equation (b) revealed that three variables are significant. The ' $t$ ' values and $F$ statistic also improved at a moderate level. ${ }^{13}$ Another variable, growth rate of exports $(G R X)$ also becomes significant. It confirms our hypothesis that capital instability is negatively related to GDP growth. To carefully assess the effect of exports instability on growth, we dropped the capital instability variable (IK) and re-estimated equation (c).

The coefficient of exports instability has a negative sign but is still insignificant. $\mathrm{F}$ statistic and $\mathrm{R}^{2}$ also fall slightly. When we compare equation (b) with equation (c), it leads to the conclusion that the more effective variable in the growth equation is capital instability rather than exports instability, in the case of India.

\subsection{1: Foreign Reserves Instability and Economic Growth}

To check the effect of foreign exchange reserves instability on economic growth, we estimated equation (5) of the model. The results of equation (5) are reported in Table 2.1. First an equation is estimated for all variables including foreign exchange instability. The coefficients of three variables, growth rate of capital, capital instability and exports instability is significant at the 1 percent level. The coefficient of a new variable foreign exchange reserve instability (IRS) is insignificant. The insignificance of IRS may be due to high correlation with $I X$ and $I K$ as discussed in the case of Pakistan too. Thus, we estimated equation (b) by omitting variable $L X$. Now four coefficients became significant, i.e. growth rate of labour, growth rate of capital, growth rate of exports and capital instability, which adds an important explanatory variable for the GDP growth of India. But foreign exchange reserve instability remained insignificant. The problem might be of correlation between $I K$ and $I R S$. Thus, to remove that we have conducted sensitivity analysis and estimated another equation (c), by omitting $I K$ and including $I X$. It appears that three variables are significant including instability in foreign exchange reserves (IRS). In this equation we identify that foreign exchange instability also affects the economic growth of India.

To identify the effect of individual variables, eg: foreign exchange instability, we estimated another equation (d), by omitting variables $I K$ and $I X$. The IRS was found significant at the 10 percent level. Two other variables,

\footnotetext{
${ }^{13}$ Variables $I K$ and $I X$ are correlated, and when we omit one of them, the results improved. For details see appendix Table .A2
} 
growth rate of labour $(G L)$ and growth rate of capital (GK) are also significant, and signs of the coefficients are according to expectations. ${ }^{14}$ Thus, export instability is not proved as a major determinant to the Indian growth process. Our results of this regression are almost similar to that of Pakistan's but the only difference is that foreign exchange reserves instability is also significant for India. Anyhow, it turns out that export instability has a minor contribution in affecting the growth of India. From the above evidence, we may conclude that exports earning instability would cause fluctuations in export earnings, a relatively unreliable source of foreign exchange earnings for investment purposes. Thus, it requires alternative funding sources in order to smooth out the uncertainties in investment funds. The impact of export instability on economic growth is through capital formation and foreign exchange needed for capital goods imports. Moreover, the stock of foreign reserves in India is greater than other South Asian countries, ${ }^{15}$ so greater reserves are more affected by fluctuations in capital formation and hence the greater impact on economic growth. Thus, it appears that in the case of India, fluctuations in capital formation and foreign exchange reserves will both be more detrimental to economic growth rather than fluctuations in export earnings ${ }^{16}$.

\footnotetext{
${ }^{14}$ Qaisrani (1996) also found the same results for Pakistan.

15 For details see IFS (various issues), from 1970-80 the annual average reserves for India, Pakistan, Bangladesh and Sri Lanka are \$3,095, \$332, \$248 and \$174 million US \$ respectively, and for 1970-99 for these countries are \$8,181, \$770, \$898 and \$678 million, respectively.

${ }^{16}$ It may be noted that a major source of financing of foreign exchange is foreign loans.
} 
Table 2.1: India: Export Instability, Capital Instability and Economic Growth: Results of Multiple Regression Equation (Dependent Variable is GDP Growth),

\begin{tabular}{|c|c|c|c|c|}
\hline Variables & (a) & (b) & (c) & (d) \\
\hline $\mathrm{C}$ & $\begin{array}{l}5.387 \\
(2.613) *\end{array}$ & $\begin{array}{l}0.323 \\
(0.18)\end{array}$ & $\begin{array}{l}3.298 \\
(1.155)\end{array}$ & $\begin{array}{l}0.62 \\
(0.175)\end{array}$ \\
\hline$G L$ & $\begin{array}{l}-0.96 \\
(-1.639)\end{array}$ & $\begin{array}{l}1.028 \\
(1.67)^{* * *}\end{array}$ & $\begin{array}{l}1.0551 \\
(1.776)^{* * *}\end{array}$ & $\begin{array}{l}1.32 \\
(2.01)^{* *}\end{array}$ \\
\hline$G K$ & $\begin{array}{l}0.201 \\
(2.82)^{*}\end{array}$ & $\begin{array}{l}0.397 \\
(8.51)^{*}\end{array}$ & $\begin{array}{l}0.277 \\
(2.816)^{*}\end{array}$ & $\begin{array}{l}0.47 \\
(2.86)^{*}\end{array}$ \\
\hline$G R \boldsymbol{X}$ & $\begin{array}{l}0.035 \\
(1.102)\end{array}$ & $\begin{array}{l}0.35 \\
(1.834) * * *\end{array}$ & $\begin{array}{l}0.017 \\
(0.488)\end{array}$ & $\begin{array}{l}0.04 \\
(0.97)\end{array}$ \\
\hline IK & $\begin{array}{l}-2860.51 \\
(-3.539)^{*}\end{array}$ & $\begin{array}{l}-1215.039 \\
(-4.123)^{*}\end{array}$ & - & - \\
\hline $\boldsymbol{L X}$ & $\begin{array}{l}-2338.89 \\
(-3.27)^{*}\end{array}$ & - & $\begin{array}{l}-1823.43 \\
(-1.56)\end{array}$ & - \\
\hline IRS & $\begin{array}{l}-240.19 \\
(-0.741)\end{array}$ & $\begin{array}{l}-383.88 \\
(-1.304)\end{array}$ & $\begin{array}{l}-371.087 \\
(-1.77)^{* * *}\end{array}$ & $\begin{array}{l}-586.9 \\
(-1.95)^{* * *}\end{array}$ \\
\hline $\operatorname{AR}(1)$ & - & - & - & $\begin{array}{l}-0.38 \\
(-1.79)^{* * *}\end{array}$ \\
\hline MA(1) & $\begin{array}{l}-0.989 \\
(-2.814)\end{array}$ & $\begin{array}{l}-0.98 \\
(-3.578)^{*}\end{array}$ & $\begin{array}{l}-1.39 \\
(-5.68)^{*}\end{array}$ & - \\
\hline $\mathbf{R}^{2}$ & 0.66 & 0.73 & 0.64 & 0.69 \\
\hline D.W & 1.98 & 1.91 & 1.95 & 2.05 \\
\hline F stat. & 4.73 & 4.59 & 10.16 & 3.92 \\
\hline
\end{tabular}

Note: Figures in Parentheses are t-statistics.

*Significant at 1 percent. ${ }^{* *}$ Significant at 5 percent. ${ }^{* * *}$ Significant at 10 percent. $G L=$ Average annual percent growth rate of the labour force. $G K=$ Growth rate of Capital, measured as the mean annual gross domestic investment as a percentage of GDP. $G R X=$ Average annual percent growth rate of exports.

$I K=$ Capital instability. $\quad I X=$ Export instability. $I R S=$ Instability in foreign exchange reserves.

\section{3: Empirical Evidence pertaining to Bangladesh}

To investigate the hypothesis that capital instability is more harmful than export instability to economic growth for Bangladesh, we estimated equation (4) and equation (5) of the model. The results of these equations are reported in Tables 3 and 3.1. 
First, equation (a) of Table 3 is estimated by using all explanatory variables of equation (4). On the basis of ' $t$ ' values, the results indicate that just a single coefficient of capital instability is significant at the 5 percent level of significance. All other variables are insignificant. This means capital instability is affecting economic growth of Bangladesh more than export instability.

Table: 3. Bangladesh: Export instability, capital instability and economic growth: Results of multiple regression equation (Dependent variable is GDP growth)

\begin{tabular}{llll}
\hline Variables & $(\mathbf{a})$ & $\mathbf{( b )}$ & $\mathbf{( c )}$ \\
\hline $\mathbf{C}$ & 5.146 & 1.225 & -4.106 \\
& $(0.925)$ & $(0.279)$ & $(-0.818)$ \\
$\boldsymbol{G L}$ & 1.107 & 0.721 & 1.345 \\
& $(1.587)$ & $(1.128)$ & $(1.748)^{* * *}$ \\
$\boldsymbol{G} \boldsymbol{K}$ & 0.230 & 0.358 & 0.619 \\
& $(0.724)$ & $(1.681)^{* * *}$ & $(2.588)^{*}$ \\
$\boldsymbol{G} \boldsymbol{R} \boldsymbol{X}$ & -0.014 & 0.37 & 0.32 \\
& $(-0.261)$ & $(2.02)^{* * *}$ & $(1.85)^{* * *}$ \\
$\boldsymbol{I} \boldsymbol{K}$ & -1341.52 & -1247.06 & - \\
& $(-1.818)^{* *}$ & $(-1.813)^{* * *}$ & \\
$\boldsymbol{C X}$ & -2012.84 & - & -533.82 \\
& $(-0.965)$ & & $(-0.248)$ \\
AR(1) & - & -0.57 & - \\
& & $(-2.601)^{* *}$ & \\
MA(1) & 0.414 & 0.99 & 0.35 \\
$\mathbf{R}^{2}$ & $(1.871)^{* * *}$ & $(1247.4)^{* *}$ & $(1.96)^{* * *}$ \\
D.W & 0.54 & 0.53 & 0.51 \\
F state & 2.03 & 1.93 & 2.14 \\
\hline
\end{tabular}

Note: Figures in Parentheses are t-statistics.

*Significant at 1 percent. ${ }^{* *}$ Significant at 5 percent. ${ }^{* * *}$ Significant at 10 percent.

$G L=$ Average annual percent growth rate of the labour force. $G K=$ Growth rate of Capital, measured as the mean annual gross domestic investment as a percentage of GDP. $G R X=$ Average annual percent growth rate of exports.

$$
I K=\text { Capital instability. } I X=\text { Export instability }
$$

To analyse the effect of $I K$ separately, we omitted the variable $I X$ and estimated equation (b). The results of equation (b) revealed those three 
variables; growth rate of capital $(G K)$, growth rate of exports and capital instability are significant at the 10 percent level.

Again the negative sign of capital instability ensures that capital instability is more severe than exports instability for the Bangladesh economy. By dropping $I K$ and including $I X$ we estimated equation (c) and found that $I X$ is an insignificant variable. This leads us to conclude that the more effective variable in the growth equation is capital instability rather than exports instability for the Bangladesh economy.

\subsection{1: Foreign Reserves Instability and Economic Growth}

To test whether foreign exchange instability has a negative effect on GDP growth, we estimated equation (5) of the model for Bangladesh. The results of equation (5) are presented in Table 3.1. Equation (a) of Table 3.1 is estimated including all the variables included in the basic equation (5). Only the coefficient of capital instability is significant at the 1 percent level. The new variable, instability of foreign exchange reserves (IRS), is insignificant. The insignificance of IRS may be due to high correlation with $L X$ and $I K{ }^{17}$ In order to remove the problem, we estimated equation (b) by omitting variable $L X$. The re-estimation of the model indicated that four coefficients became significant, i.e. growth rates of labour $(G L)$ at the 10 percent level, capital $(G K)$ at the 5 percent and exports $(G R X)$ at the 10 percent and capital instability (IK) again at the 10 percent leve1. But foreign exchange reserves instability still remained insignificant. Again the problem of multi-colinearality occurs due to correlation between IK and IRS. Thus, we estimated another equation (c) by omitting $I K$ and including $I X$ and found two variables, growth rate of capital, significant at 1 percent and growth rate of exports significant at the 10 percent level. In this equation (c) of Table 3.1 we identify that foreign exchange instability is less harmful than capital instability for the economic growth of Bangladesh. This suggests that capital instability is more harmful for the economic growth of Bangladesh rather than exports and foreign exchange reserves. To analyse the individual effect of foreign exchange instability, we estimated another equation (d) by omitting variables $I K$ and $I X$. The IRS is still insignificant and two other variables, growth rate of capital $(G K)$ and growth rate of exports $(G R X)$ are significant at 5 percent and 10 percent, respectively.

\footnotetext{
${ }^{17}$ Multicollinearity problem might have arisen due to high correlation of IRS with IK and $I X$. For details see appendix table A3.
} 
In the case of Bangladesh, it may be concluded that capital instability is affecting economic growth more than the fluctuations in exports earning and foreign exchange reserves.

Table: 3.1: Bangladesh: Export Instability, Capital Instability and Economic Growth: Results of Multiple Regression Equation (Dependent Variable is GDP Growth)

\begin{tabular}{lllll}
\hline Variables & (a) & (b) & (c) & (d) \\
\hline C & 1.041 & 2.695 & -6.414 & -9.45 \\
& $(0.116)$ & $(0.398)$ & $(-1.401)$ & $(-2.06)^{*}$ \\
$\boldsymbol{G L}$ & 0.897 & 1.188 & 0.861 & 0.927 \\
& $(1.21)$ & $(1.849)^{* * *}$ & $(1.215)$ & $(1.29)$ \\
$\boldsymbol{G K}$ & 0.177 & 0.63 & 0.665 & 0.56 \\
& $(0.429)$ & $(2.629)^{* *}$ & $(2.867)^{*}$ & $(2.24)^{* *}$ \\
$\boldsymbol{G} \boldsymbol{R} \boldsymbol{X}$ & -0.041 & 0.071 & 0.06 & 0.06 \\
& $(-0.7225)$ & $(1.96)^{* * *}$ & $(1.89)^{* * *}$ & $(1.69)^{* * *}$ \\
$\boldsymbol{I K}$ & -2274.782 & -1486.47 & - & - \\
& $(-2.6237)^{*}$ & $(-1.87)^{* * *}$ & & \\
$\boldsymbol{L} \boldsymbol{X}$ & -1994.46 & - & -620.36 & - \\
& $(-0.817)$ & & $(-0.925)$ & \\
$\boldsymbol{I R S}$ & 452.87 & -687.14 & 14.065 & 124.56 \\
& $(0.687)$ & $(-1.17)$ & $(0.022)$ & $(0.268)$ \\
AR(1) & 0.603 & - & -0.585 & -0.497 \\
& $(3.354)$ & & $(-2.465)^{*}$ & $(-2.087)^{* *}$ \\
MA(1) & - & 0.47 & 0.98 & 1.15 \\
& & $(2.17)^{* *}$ & $(110.01)^{*}$ & $(2.25)^{* *}$ \\
$\mathbf{R}^{2}$ & 0.54 & 0.51 & 0.50 & 0.52 \\
D.W. & 1.93 & 2.06 & 2.04 & 1.91 \\
F stat. & 3.39 & 3.53 & 3.76 & 4.58 \\
\hline
\end{tabular}

Note: Figures in Parentheses are t-statistics.

*Significant at 1 percent. ** Significant at 5 percent. *** Significant at 10 percent. $G L=$ Average annual percent growth rate of the labour force. $G K=$ Growth rate of Capital, measured as the mean annual gross domestic investment as a percentage of GDP. $G R X=$ Average annual percent growth rate of exports. $I K=$ Capital instability.

$L X=$ Export instability. $I R S=$ Instability in foreign exchange reserve.

\subsection{Empirical Evidence pertaining to Sri Lanka}

To draw empirical evidence whether capital instability has more effect than exports instability for the economy of Sri Lanka, equation (4) and 
equation (5) of the model are estimated. The results are reported in Table 4 and 4.1, respectively. First equation (4) of Table 3.4 is estimated for all variables. Two coefficients of the variables, growth rate of capital $(G K)$ and export instability $(L X)$, are found to be significant at 10 percent. The results are surprisingly different from other South Asian countries because capital instability $(I K)$ is found to be insignificant and it does not match with our hypothesis that capital instability is more harmful than export instability for the economic growth of South Asia. However, to investigate the individual effects of capital instability we dropped export instability $(I X)$ and estimated equation (b). However, the results remained the same and $I K$ is still an insignificant variable. Growth rate of capital is still significant.

Table 3.4: Sri Lanka: Export Instability, Capital Instability and Economic Growth: Results of Multiple Regression Equation (Dependent Variable is GDP Growth)

\begin{tabular}{llll}
\hline Variables & (a) & (b) & (c) \\
\hline $\mathbf{C}$ & 4.28 & 3.295 & 3.88 \\
& $(1.095)$ & $(0.858)$ & $(1.01)$ \\
$\boldsymbol{G} \boldsymbol{G}$ & 0.125 & 0.293 & 0.059 \\
$\boldsymbol{G} \boldsymbol{K}$ & $(0.179)$ & $(0.413)$ & $(0.08)$ \\
& 0.301 & 0.352 & 0.307 \\
$\boldsymbol{G} \boldsymbol{R} \boldsymbol{X}$ & $(1.856)^{* * *}$ & $(2.17)^{* *}$ & $(1.91)^{* * *}$ \\
& 0.001 & 0.001 & 0.02 \\
$\boldsymbol{I} \boldsymbol{K}$ & $(0.105)$ & $(0.023)$ & $(1.99)^{* * *}$ \\
& -466.7 & -642.27 & - \\
$\boldsymbol{C} \boldsymbol{( - 0 . 7 4 )}$ & -3520.11 & $(-1.01)$ & \\
& $(-1.77)^{* * *}$ & - & -3733.731 \\
$\mathbf{R}^{2}$ & 0.54 & & $(-1.921)^{* * *}$ \\
D.W. & 1.96 & 0.52 & 0.55 \\
F stat. & 3.85 & 1.96 & 2.01 \\
\hline
\end{tabular}

Note: Figures in Parentheses are t-statistics.

*Significant at 1 percent. ** Significant at 5 percent. *** Significant at 10 percent. $G L=$ Average annual percent growth rate of the labour force. $G K=$ Growth rate of capital, measured as the mean annual gross domestic investment as a percentage of GDP. $G R X=$ Average annual percent growth rate of exports.

$I K=$ Capital instability. $I X=$ Export instability. 
In the next equation (c), we omitted variable $I K$ and included variable $L X$. The results are presented in Table 4 , which indicate that export instability is significant at the 10 percent level. Two other coefficients of variables, growth rate of capital $(G K)$, and growth rate of exports $(G R X)$, are also significant at the 10 percent level. The results of equation (c) indicate that export instability is affecting economic growth more than capital instability in Sri Lanka. The reason could be that Sri Lanka is a country which is following out-ward looking policies and it is dependent upon the imports of even food items. However, it faces shortage of capital and, thus, exports instability is a more detrimental factor for its GDP growth than capital. ${ }^{18}$

\subsection{Effect of Instability in Foreign Reserves on Growth.}

The variable, foreign exchange reserves instability, which we have included for Pakistan, India, and Bangladesh, is also included for Sri Lanka. By including this new variable in equation (5) we checked its effect on the GDP growth rate. The results of equation (5) are presented in Table 4.1. First, the equation is estimated for all variables including foreign exchange instability. The coefficients of two variables, growth rate of exports and exports instability are found to be significant at 5 and 10 percent, respectively. The new variables, i.e. instability in foreign exchange reserves (IRS) and capital instability (IK) are not found to be significant variables. The insignificance of $I R S$ may be due to high correlation between $I X$ and $I K^{19}$ Thus, we estimated equation (b) by omitting the variable $L X$. Now again capital instability $(L X)$ is found to be insignificant but growth rate of capital $(G K)$ is significant at the 10 percent level. Again the problem of multicollinearity occurs due to correlation between $I K$ and IRS. Thus, we estimated another equation (c) by omitting $I K$ and including $I X$ and found the two variables, growth rate of capital (IK) and export instability $(L X)$, which was significant at the 10 percent level.

To analyse the separate effect of foreign exchange instability, we estimated another equation (d) by omitting variables $I K$ and $I X$. It appears that IRS is still insignificant and two other variables, growth rate of capital $(G K)$ and growth rate of exports $(G R X)$, are significant at 10 percent.

In the case of Sri Lanka, the most important variables regarding GDP growth is the growth rate of capital $(G K)$, growth rate of exports

\footnotetext{
${ }^{18}$ From 1970-80 the annual average gross domestic investment for Sri Lanka was \$ 1143 million, whereas, for India, Pakistan, and Bangladesh, it was \$29,536, \$3,333 and $\$ 3,071$ million, respectively. In 1990-98, for Sri Lanka it is 3190, but for India, Pakistan and Bangladesh, it was $\$ 81,188, \$ 8,968$, and $\$ 7,376$ million, respectively. For details see WDI (various Issues).

${ }^{19}$ For details see Appendix Table A4.
} 
$(G R X)$ and export instability $(L X)$. It suggests that growth rate of capital can accelerate growth but fluctuations in capital may not greatly affect the economic growth of Sri Lanka. Given the above-cited empirical evidence pertaining to Sri Lanka, it may be concluded that export instability is affecting economic growth more than capital and foreign exchange reserves instability. Basically, Sri Lanka has less capital and is a more export-based economy, the very reason that capital instability is less effective for its economic growth.

Table 4.1: Sri Lanka: Export Instability, Capital Instability and Economic Growth: Results of Multiple Regression Equation (Dependent Variable is GDP Growth).

\begin{tabular}{|c|c|c|c|c|}
\hline Variables & (a) & (b) & (c) & (d) \\
\hline $\mathrm{C}$ & $\begin{array}{l}5.49 \\
(0.89)\end{array}$ & $\begin{array}{l}4.1 \\
(1.033)\end{array}$ & $\begin{array}{l}4.047 \\
(1.038)\end{array}$ & $\begin{array}{l}1.90 \\
(1.26)\end{array}$ \\
\hline$G L$ & $\begin{array}{l}0.429 \\
(0.693)\end{array}$ & $\begin{array}{l}0.277 \\
(0.394)\end{array}$ & $\begin{array}{l}0.089 \\
(0.128)\end{array}$ & $\begin{array}{l}0.11 \\
(0.42)\end{array}$ \\
\hline$G \boldsymbol{K}$ & $\begin{array}{l}0.345 \\
(1.379)\end{array}$ & $\begin{array}{l}0.313 \\
(1.91)^{* * *}\end{array}$ & $\begin{array}{l}0.302 \\
(1.85)^{* * *}\end{array}$ & $\begin{array}{l}0.105 \\
(1.701)^{* * * *}\end{array}$ \\
\hline$G R \boldsymbol{X}$ & $\begin{array}{l}0.102 \\
(2.27)^{* * *}\end{array}$ & $\begin{array}{l}-0.0015 \\
(-0.182)\end{array}$ & $\begin{array}{l}0.002 \\
(0.084)\end{array}$ & $\begin{array}{l}0.024 \\
(1.724)^{* * *}\end{array}$ \\
\hline$I K$ & $\begin{array}{l}-1496.75 \\
(-1.656)\end{array}$ & $\begin{array}{l}-598.87 \\
(-0.945)\end{array}$ & - & - \\
\hline $\boldsymbol{L} \boldsymbol{X}$ & $\begin{array}{l}-2339.36 \\
(-1.805)^{* * *}\end{array}$ & - & $\begin{array}{l}-28994.96 \\
(-1.83)^{* * * *}\end{array}$ & - \\
\hline IRS & $\begin{array}{l}-563.51 \\
(-0.887)\end{array}$ & $\begin{array}{l}-778.99 \\
(-1.535)\end{array}$ & $\begin{array}{l}-375.306 \\
(-0.616)\end{array}$ & $\begin{array}{l}-77.89 \\
(-0.404)\end{array}$ \\
\hline $\operatorname{AR}(1)$ & $\begin{array}{l}0.405 \\
(1.756) * * *\end{array}$ & - & - & - \\
\hline $\mathbf{R}^{2}$ & 0.52 & 0.51 & 0.56 & 0.52 \\
\hline D.W & 1.91 & 1.94 & 2.01 & 2.03 \\
\hline F state & 3.61 & 3.66 & 3.81 & 3.61 \\
\hline
\end{tabular}

Note: Figures in Parentheses are t-statistics.

*Significant at 1 percent. ** Significant at 5 percent. *** Significant at 10 percent. $G L=$ Average annual percent growth rate of the labour force. $G K=$ Growth rate of Capital, measured as the mean annual gross domestic investment as a percentage of GDP. $G R X=$ Average annual percent growth rate of exports. $I K=$ Capital instability. $I X=$ Export instability. $I R S=$ Instability in foreign exchange reserves. 


\section{Conclusion and Policy Implications}

The study aimed to highlight the role of capital instability and trade instability in the economic growth of South Asia. The impact of these instabilities was analysed in terms of their impact on economic growth. Besides, also explored was whether capital instability or exports instability, in relative terms, is affecting economic growth more in the South Asian countries. In addition, the impact of foreign exchange instability on economic growth was also explored. The empirical evidence indicates that capital instability affects economic growth more than export instability for Pakistan, India and Bangladesh. But in the case of Sri Lanka exports instability is found to have a significant impact on economic growth rather than capital instability. It may be due to the reason that limited capital stock is likely to be less mobile in the case of Sri Lanka and the country is much more dependent upon imports like basic food items. Moreover, it is following an outward looking policy for its economic growth. Consequently, export earnings have a significant role in its economy. Thus, export instability being the major determinant of growth is negatively affecting its growth process, having a larger magnitude. Besides, other variables like growth rate of labour $(G L)$, growth rate of capital $(G K)$, and growth rate of exports (GRK) were also found to be significant determinants of economic growth. For Pakistan, India, and Bangladesh, fluctuations in capital stocks have a significant impact on the growth performance of these countries. In these countries, with the passage of time, stocks of capital are mobile. The fluctuations in capital stocks have greater magnitude than fluctuations in export earnings. Therefore, fluctuations in capital stock affect the economic growth of Pakistan, India and Bangladesh more.

The other most important variable is instability in foreign exchange reserves, which is insignificant for all the countries except India. It may be stated that foreign exchange reserves do not significantly affect the economic growth of Pakistan, Bangladesh and Sri Lanka. However, India has larger foreign exchange reserves than other South Asian countries. As reserves are greater in India, therefore, it has a stronger effect on its economic growth. In brief, it may be concluded that capital instability is affecting the economic growth of Pakistan, India, and Bangladesh more. Besides, the instability of foreign exchange reserves also appeared the major affecting variable for the Indian economy. Thus, India must also focus on stabilising foreign reserves. Similarly, Sri Lanka may also concentrate on trade instability. For other South Asian countries, it is important that they pay more attention to stabilising capital formation rather than trade. It may be noted that the trade volume of most of these countries is not very large, which means that their dependency on foreign trade is not very much. For 
sustained economic growth these countries need to pay immediate policy attention towards capital formation. For example, it is evident that in Pakistan, recently its failure to mobilise capital led to a slow down in its economic growth. A similar situation may prevail in other South Asian countries, except India. The findings pertaining to South Asia may also be applicable to other developing countries. Further research in this regard could help to sustain economic growth in developing countries.

\section{Appendix 1: The Model}

$Q=F(K, L)$

$\ln Q=\ln F(K, L)$

By taking total differential

$\frac{1}{Q} d Q=\frac{1}{Q}\left[F_{K} \cdot d K+F_{L} \cdot d L\right]$

Multiplying by $\frac{K}{K}$ and $\frac{L}{L}$

$\frac{d Q}{Q}=\frac{K}{Q} \cdot F_{K} \cdot \frac{d K}{K}+\frac{L}{Q} \cdot F_{L} \cdot \frac{d L}{L}$

$G Y=\alpha\left[\frac{(I-D)}{K}\right]+\beta \frac{d L}{L}$

Where $\frac{d Q}{Q}=G Y$ and $\frac{K}{Q} \cdot F_{K}=\alpha$ and $d K=I-D$ (net investment $)$

$G Y=\alpha\left[\frac{I}{K}-\delta\right]+\beta G L$

Where $G L=$ growth rate of labour and $\delta$ is depriciation rate

$G Y=-\alpha \delta+\left[\alpha \cdot \frac{I}{K}\right]+\beta G L$

Multiplying by $\frac{Y}{Y}$ we get

$G Y=-\alpha \delta+\left[\alpha \cdot \frac{I}{K}\right] \cdot \frac{Y}{Y}+\beta G L$

$G Y=\alpha_{1}+\left[\alpha \cdot \frac{Y}{K}\right] \cdot \frac{I}{Y}+\beta G L$

Where $\alpha_{1}=-\alpha \delta$

$G Y=\alpha_{1}+\alpha_{2} \frac{I}{Y}+\beta G L$

Where $\alpha_{2}=\alpha \cdot \frac{Y}{K}$

and $\frac{I}{Y}$ is proxy for growth rate of capital, which ismeasured as gross domesticinvestment as percentage of GNP. 
Appendix Table A.1: Correlation matrix: Exports, Capital Instability and Economic Growth Correlation Matrix for Pakistan

\begin{tabular}{lcccrccc}
\hline & GQ & GL & \multicolumn{1}{l}{ GK } & GRX & \multicolumn{1}{l}{ IK } & IX & \multicolumn{1}{l}{ IRS } \\
\hline GQ & 1.000 & 0.134 & 0.408 & 0.466 & -0.561 & -0.373 & -0.161 \\
GL & 0.133 & 1.000 & -0.138 & -0.227 & -0.022 & -0.052 & 0.116 \\
GK & 0.408 & -0.138 & 1.000 & 0.045 & -0.730 & -0.338 & 0.101 \\
GRX & 0.466 & -0.227 & 0.045 & 1.000 & -0.087 & 0.350 & 0.145 \\
IK & -0.561 & -0.022 & -0.730 & -0.087 & 1.000 & 0.743 & 0.799 \\
IX & -0.372 & -0.053 & -0.338 & 0.350 & 0.743 & 1.000 & 0.028 \\
IRS & -0.161 & 0.116 & 0.101 & 0.145 & 0.799 & 0.028 & 1.000 \\
\hline
\end{tabular}

$\mathrm{GQ}=$ Growth rate of GDP.

$\mathrm{GL}=$ Average annual percent growth rate of the labour force. GK = Growth rate of capital, measured as mean annual gross domestic investment as a percentage of GDP. GRX = Average annual per cent growth rate of exports. IK = Capital instability. IX = Export instability. IRS= Instability in foreign exchange reserves.

Appendix Table A.2: Correlation matrix: Exports, Capital Instability and Economic Growth Correlation Matrix for India

\begin{tabular}{lccccccc}
\hline & GQ & GL & GK & GRX & IK & \multicolumn{1}{c}{ IX } & IRS \\
GQ & 1.000 & 0.029 & 0.389 & 0.055 & -0.551 & -0.116 & -0.512 \\
GL & 0.029 & 1.000 & 0.108 & -0.276 & -0.209 & 0.173 & -0.167 \\
GK & 0.389 & -0.108 & 1.000 & -0.096 & -0.349 & -0.539 & 0.003 \\
GRX & 0.055 & -0.276 & -0.096 & 1.000 & 0.362 & 0.209 & -0.022 \\
IK & -0.551 & -0.209 & -0.349 & 0.362 & 1.000 & -0.622 & -0.741 \\
IX & -0.116 & 0.173 & -0.539 & 0.209 & -0.622 & 1.000 & 0.137 \\
IRS & -0.512 & -0.167 & 0.003 & -0.022 & -0.741 & 0.137 & 1.000 \\
\hline
\end{tabular}

$\mathrm{GQ}=$ Growth rate of GDP. GL = Average annual percent growth rate of the labour force.

GK = Growth rate of Capital, measured as mean annual gross domestic investment as a percentage of GDP. GRX = Average annual per cent growth rate of exports. $\mathrm{IK}=$ Capital instability.IX $=$ Export instability. IRS = Instability in foreign exchange reserves. 
Appendix Table A.3: Correlation Matrix: Exports, Capital Instability and Economic Growth, Correlation Matrix for Bangladesh

\begin{tabular}{lcccccrr}
\hline & GQ & GL & GK & GRX & \multicolumn{1}{c}{ IK } & \multicolumn{1}{c}{ IX } & \multicolumn{1}{c}{ IRS } \\
\hline GQ & 1.000 & 0.283 & 0.425 & 0.227 & -0.572 & -0.207 & -0.091 \\
GL & 0.283 & 1.000 & 0.054 & -0.006 & 0.036 & 0.013 & 0.203 \\
GK & 0.425 & 0.054 & 1.000 & 0.039 & -0.631 & -0.339 & 0.162 \\
GRX & 0.227 & -0.006 & 0.039 & 1.000 & -0.384 & -0.452 & -0.098 \\
IK & -0.572 & 0.036 & -0.631 & -10.384 & 1.000 & 0.662 & 0.222 \\
IX & -0.207 & 0.013 & -0.339 & -0.452 & 0.662 & 1.000 & -0.330 \\
IRS & -0.091 & 0.203 & 0.162 & -0.098 & 0.222 & -0.330 & 1.000 \\
\hline
\end{tabular}

$\mathrm{GQ}=$ Growth rate of GDP. GL = Average annual percent growth rate of the labour force.

$\mathrm{GK}=$ Growth rate of capital, measured as mean annual gross domestic investment as a percentage of GDP. GRX = Average annual per cent growth rate of exports.

$\mathrm{IK}=$ Capital instability. IX = Export instability. IRS= Instability in foreign exchange reserves.

Appendix Table : A. 4, Correlation matrix: Exports, Capital Instability and Economic Growth Correlation Matrix for Sri Lanka

\begin{tabular}{lccccccc}
\hline & GQ & GL & GK & GRX & IK & IX & IRS \\
\hline GQ & 1.000 & 0.114 & 0.494 & 0.327 & -0.299 & -0.598 & -0.327 \\
GL & 0.114 & 1.000 & 0.090 & -0.170 & 0.140 & -0.106 & 0.028 \\
GK & 0.494 & 0.090 & 1.000 & 0.114 & 0.074 & 0.165 & 0.124 \\
GRX & 0.327 & -0.170 & 0.114 & 1.000 & -0.138 & 0.065 & -0.126 \\
IK & -0.299 & 0.140 & 0.074 & -0.138 & 1.000 & 0.432 & 0.659 \\
IX & -0.598 & -0.106 & 0.165 & 0.065 & 0.432 & 1.000 & 0.561 \\
IRS & -0.327 & 0.028 & 0.124 & -0.126 & 0.659 & 0.561 & 1.000 \\
\hline GQ= Growth rate of GDP. GL = Average annual percent growth rate of the
\end{tabular}
labour force.

GK = Growth rate of Capital, measured as mean annual gross domestic investment as a percentage of GDP. GRX = Average annual percent growth rate of exports.

$\mathrm{IK}=$ Capital instability. IX = Export instability. IRS= Instability in foreign exchange reserves. 


\section{References}

A1-Marhubi, Fahim, 2000, 'Export Diversification and Growth: An Empirical Investigation', Applied Economics Letters, Vo1.7, pp.559-562.

Athukorala, P. and Huynh, F. Heip, 1986, Export Instability and Growth: Problems and Prospects for the Developing Economies, Worcester: Billing \& Sons Limited.

Balassa, B., 1978, 'Exports and Economic Growth: Further Evidence', Journal of Development Economics, Vo1.5, pp.181-189.

Balassa, B., 1985, 'Export Policy Choices, and Economic Growth in Developing Countries After the 1973 Oil Shock', Journal of Development Economics, Vo1.18, pp.23-35.

Coppock, J.D., 1962, International Economics Instability, New York: McGraw Hill.

David, Dawe, 1996, 'A New Look at the Effects of Export Instability on Investment and Growth', World Development, Vo1.24, No.12, pp.1905-14.

Feder, Gershon, 1982, 'On Exports and Economic Growth', Journal of Development Economics, Vo1.12, pp.59-73.

Fosu, A. K., 1991, 'Capital Instability and Economic Growth in Sub-Saharan Africa', Journal of Development Studies, Vo1.28, No.1, pp.74-85.

Fosu, A.K., 1992, 'Effect of Export Instability on Economic Growth in Africa', Journal of Developing Areas, Vo1.26, pp.323-332.

Glezakos, C., 1973, 'Export Instability and Economic Growth: A Statistical Verification', Economic Development and Cultural Change, Vol.21, No.4, pp.670-678.

Glezakos, C., 1984, 'Export Instability and Economic Growth: Reply', Economic Development and Cultural Change, Vo1.32, pp.615-623.

Gundlach, Erich, 1997, 'Openness and Economic Growth in Developing Countries'.

Weltwirtschaftliches Archiv, Vo1.133, No.3, pp.479-496. 
Hirschman, A. O., 1945, National Power and the Structure of Foreign Trade, Berkeley and Los Angeles: University of California Press.

IMF (International Monetary Fund), 2000, Direction of Trade Statistics, 2000, Washington DC: Oxford University Press. (Various Issues).

IMF (International Monetary Fund), 2000, International Financial Statistics, 1995, Washington DC: Oxford University Press. (Various Issues).

Kenen, P. B. and C. S. Voivodas, 1972, 'Export Instability and Economic Growth', Kyklos, Vo1.25, pp.791-804.

Lancieri, D., 1978, 'Instability and Economic Development: A Reappraisal', Banka Nazionale Del Lavoro Quarterly Review, Vo1.32, pp.135-152.

Lawson, C. W., 1974, 'The Decline in World Export Instability - A Reappraisal', Oxford Bulletin of Economics and Statistics, Vo1.36, pp.53-65.

Levine, R. and D. Renelt, 1992, 'A Sensitivity Analysis of Cross-Country Growth Regression', American Economic Review, Vo1.82, No.4, pp.942-963.

Lim, D., 1976, 'Export Instability and Economic Growth - Return to Fundamentals', Oxford Bulletin of Economics and Statistics, Vol.38, pp.311-322.

Love, J., 1992, 'Export Instability and the Domestic Economy: Question of Causality', Journal of Development Studies, Vo1.28, No.4, pp.735-742.

MacBean, A. I., 1966, Export Instability and Economic Development, Cambridge, MA: Harvard University Press.

MacBean, A. I., 1976, 'Review of Trade Instability and Economic Development by Knudsen and Parnes', Journal of Development Studies, Vol.13, pp.117-120.

Mahmood, 1981, 'Changes in Export Shares and Competitive Strength in Pakistan', Pakistan Development Review, Vo1.20, No.4, pp.25-37.

Mahmood, D., 1998, 'WTO and Pakistan: Opportunities and Policy Challenges', Pakistan Development Review, Vo1.37, No.4, pp.687-701.

Maizels, Alfred, 1968, Exports and Economic Growth of Developing Countries, London: Cambridge University Press. 
Manjappa, H. D. and H.V. Ishwar, 1999, 'Import-led Growth-led Export: A New Trade-Development Mode1 for Developing Countries', Indian Economic Journal, Vo1.45, No.3, pp.100-118.

Masse11, Benton E., 1970, 'Export instability and Economic Structure', American Economic Review, Vo1.32, pp.618-630.

Masse11, Benton F., S.R. Pearson and J.B. Finch, 1972, 'Foreign Exchange and Economic Development: An Empirical Study of Selected Latin American Countries', The Review of Economics and Statistics, Vol.54, No.2, pp.208-212.

Michaely, Michae1, 1977, 'Export and Growth: An Empirical Investigation', Journal of Development Economics, Vol.11, pp.141-54.

Moran, C., (1983), 'Export Fluctuations and Economic Growth: An Empirical Analysis', Journal of Development Economics, Vo1.12, pp.195-218.

Qaisrani, A. Ahmed, 1996, 'Foreign Trade, Export Instability and Economic Growth in Pakistan', M.Phil Dissertation, Quaid-i-Azam University., Islamabad.

Saleem, M., 2000, 'Patterns of Pakistan's Exports, Instability and its Future Prospects', M.Phil Dissertation, Quaid-i-Azam University., Islamabad.

Savvides, Amdreas, 1984, 'Export Instability and Economic Growth: Some New Evidence', Economic Development and Cultural Change, Vol.32, No.3, pp.607-614.

Sharif, Muhammad, 1981, 'Trade Growth and Income Redistribution: A Case Study of India', Journal of Development Economics, Vo1.9, pp.131147.

Sinha, Dipendra, 1999, 'Export Instability, Investment and Economic Growth in Asian Countries: A Time Series Analysis, Center Discussion Paper No.799', Economic Growth Center, Yale University.

Sprout, V. A. Ronald and Weaver H. James, 1993, 'Exports and Economic Growth in a Simultaneous Equations Model', Journal of Developing Areas, Vo1.27, pp26-32.

Sundrum, R. M., 1976, 'Review of Trade Instability and Economic Development, by Knudsen and Parens', Journal of Political Economy,Vol.84, pp.897-899. 
Tariq, and Najeeb, 1995, 'Export Earning Fluctuations and Economic Growth', Pakistan Development Review, Vo1.34, No.4, pp.1181-1189.

Tyler, William G., 1981, 'Growth and Export Expansion in Developing Countries', Journal of Development Economics, Vo1.9, pp.121-30.

UN (United Nations), 1999, Yearbook of International Commodity Statistics, Washington DC: Oxford University Press. (Various Issues).

Voivodas, C.S., 1974, 'The Effect of Foreign Exchange Instability on Growth', Review of Economics and Statistics, Vo1.56, No. 3, pp.410-412. 